\title{
Lideranças estrangeiras entre os trabalhadores manauaras (1910-1930)
}

\author{
Luís Balkar Sá Peixoto Pinheiro*
}

Resumo: O artigo aborda a trajetória de três militantes estrangeiros - o italiano Targino Mariani, o espanhol Joaquim Azpilicueta e o português Tércio Miranda no interior do movimento operário manauara das três primeiras décadas do século $\mathrm{XX}$, buscando informar os vínculos ideológicos e as perspectivas político-sindicais por eles assumidas, além de analisar suas atuações, interações e oposições tanto entre si quanto com outras lideranças e trabalhadores amazonenses na construção de suas identidades operárias.

Palavras-chave: história do trabalho; movimento operário; militantes estrangeiros.

\begin{abstract}
This article discusses the trajectory of three foreign militants - the Italian Targino Mariani, the spaniard Joaquim Azpilicueta and the portuguese Tércio Miranda - in the interior of the workers' movement in the city of Manaus of the first three decades of the 2oth century, seeking to inform the ideological links and the political-syndicalist perspectives that they undertook, as well as analyzing their actions, interactions and oppositions, both among themselves and with other Amazonian leaders and workers during the construction of their identities as workers.
\end{abstract}

Keywords: history of labor; labor movement; foreign militants.

O adensamento recente das pesquisas acerca do trabalho e dos trabalhadores urbanos na capital amazonense da virada do século XIX para o XX, em que pese ainda não ter esgotado questões sobre temas centrais como jornada e regime de trabalho, salários, moradia, ou mesmo protestos e greves operárias, tem permitido, contudo, iluminar a atuação de algumas das principais lideranças que atuaram no movimento operário amazonense daquele período.

Objetivando contribuir para o debate, este artigo busca situar a atuação de algumas lideranças estrangeiras que se fizeram presentes e ganharam destaque no interior do movimento operário amazonense da Primeira República, buscando compreender as dimensões e limites de suas atuações e inquirindo acerca de como foram ali percebidos e recepcionados. A opção por estudá-los parte do reconhecimento de que, ao longo de toda a República Velha, questões relacionadas

* Doutor em História pela PUC-SP e professor associado da Universidade Federal do Amazonas. E-mail: balkar.ufam@gmail.com. 
à identidade étnica da classe operária amazonense foram bastante sensíveis, produzindo conflitos e animosidades de proporções diversas entre nacionais e estrangeiros.

A relação com os estrangeiros no Amazonas sempre foi tensa, e o estado chegou mesmo a presenciar movimentos mata galegos em fins do século XIX. ${ }^{1}$ Exemplos desses conflitos entre nacionais e estrangeiros no interior do movimento operário apareceram também desde o final do século XIX e espraiaram-se pelas décadas seguintes. Assim, em 1892, quando o discurso de um líder operário local pela imprensa defendendo a criação de um partido operário e que o mesmo se mantivesse em oposição a Floriano Peixoto foi alvo de um contraprotesto assinado por uma centena de trabalhadores; a tréplica, assinada por Joaquim Carvalho, foi no sentido de desqualificar a denúncia, com o argumento excludente de que os contestadores eram "em grande número estrangeiros", e que a esses era "vedada a intervenção na política do país". ${ }^{2}$ Em 1914, a reprodução de telegramas falsos por um grande jornal da imprensa amazonense (o Amazonas), dando conta que um grupo de carbonários portugueses havia invadido a embaixada brasileira em Lisboa e rasgado a bandeira brasileira, provocou em Manaus uma onda de graves protestos, saques e ataques a membros da colônia portuguesa. ${ }^{3}$ Por fim, em 1921, quando o Centro Operário Amazonense, constituído quase que exclusivamente por lideranças nacionais, no âmbito de uma greve parcial na cidade produziu um regulamento que impunha que patrões e mestres ligados à construção civil deveriam admitir, obrigatoriamente, cinquenta por cento de "operários artistas brasileiros", a reação da categoria, em boa medida constituída de portugueses e espanhóis, foi imediata e incisiva, fragilizando o movimento paredista. ${ }^{4}$

Diante dos conflitos étnicos que alcançavam a nascente classe operária amazonense, as lideranças nacionais dividiram-se. De um lado, lideranças como Alfredo Vasconcelos Lins (1905) ou Manoel Sérvulo (1920) defendiam um movimento operário sem bandeiras e avesso aos nacionalismos e segmentações étnicas; enquanto, de outro lado, militavam os que, como o Centro Operário Amazonense (1919), defendiam melhorias e "salvaguardas" aos trabalhadores nacionais. É importante ressaltar que tais fenômenos ocorriam em Manaus em paralelo a manifestações de igual teor em outras áreas do país. Estudando o contexto paulista, Sheldon Maram, por exemplo, apontou que os conflitos étnicos foram frequentes ali. Para o autor, a razão desses conflitos estava no fato de que

...o operariado brasileiro, marginalizado nas profissões subalternas e não qualificadas, não possuía uma tradição de classe na qual pudesse basear-se. Ressentia-se do sentido de superioridade cultural e até mesmo racial que o imigrante ostentava sobre ele. Por sua vez, os imigrantes militantes ressentiam-se dos brasileiros por estarem prestes a melhorar de vida substituindo-os durante as greves. ${ }^{5}$

1 O tema tem sido explorado pela historiografia, tanto nacional quanto regional, produzindo boas interpretações: RIBEIRO, Gladys Sabino. Mata galegos: Os portugueses e os conflitos de trabalho na República Velha. São Paulo: Brasiliense, 1990; PINHEIRO. "Portugueses letrados na Amazônia: Imprensa, política e etnicidade (1885-1937)". (Tese de doutorado, Universidade do Porto, 2012).

2 Diário de Manáos, Manaus, 29 ago. 1892.

3 Amazonas, Manaus, 15 ago. 1914; A União, Manaus, 26 set. 1914.

4 Jornal do Comércio, Manaus, 7 abr. 1921

5 MARAM, Sheldon Leslie. Anarquistas, imigrantes e o movimento operário brasileiro, 1890-1920. Rio de Janeiro: Paz e Terra, 1979, p. 30. 
Já o posicionamento das principais lideranças estrangeiras que atuaram em Manaus demonstra uma clara trajetória no sentido da condenação às dissidências étnicas e ao uso de recortes ancorados em nacionalidades para qualquer finalidade no âmbito da organização e da luta operária amazonense, o que atribui importância ao estudo de tais lideranças. Os registros documentais do período, embora escassos e fragmentários, registraram a passagem por Manaus e a atuação na cidade de pelo menos três importantes militantes estrangeiros, a saber: o português Tércio Miranda, o espanhol Joaquim Azpilicueta e o italiano Targino Mariani. Tais líderes, para além das nacionalidades diferenciadas, traziam ainda outras características distintivas entre si, estando essas ligadas aos espectros ideológicos que abraçaram ao longo de suas vidas e a partir dos quais buscaram interagir, influenciar e direcionar a ação dos trabalhadores amazonenses.

O italiano Targino Mariani, assumindo desde sua chegada a Manaus o trabalho da estiva, perfilou-se sempre pela tradição reformista e, até as vésperas da ascensão do trabalhismo, manteve-se como atuante liderança dos estivadores amazonenses. O espanhol Joaquim Azpilicueta, trabalhador gráfico que também trilhou o caminho das letras e do jornalismo, vinculava-se ao ideário socialista, associado às ideias de Marx e Engels. Já o português Tércio Miranda, trabalhador gráfico, clicherista e pioneiro no desenvolvimento e introdução de técnicas de fotogravura em Manaus, foi o nome mais destacado na defesa do sindicalismo revolucionário.

A exiguidade da documentação torna extremamente difícil responder a contento sobre questões relevantes, como seja, o de precisar o momento em que esses indivíduos se lançaram à militância operária, ou ainda se o fizeram em seus países de origem ou já em solo brasileiro, como fruto da interação com outros militantes e trabalhadores nacionais. Talvez seja mais profícuo assumir a perspectiva adotada por Edilene Toledo que, ao investigar a trajetória de três lideranças sindicais no país, argumenta que "os militantes italianos que viveram no Brasil tanto trouxeram quanto levaram experiências políticas e sindicais", significando, portanto, que "a formação do sindicalismo enquanto um fenômeno internacional era favorecida pela circulação de ideias e práticas levadas por esses militantes de um país a outro". ${ }^{6}$

Outro ponto importante a ser destacado de imediato é que tanto Tércio Miranda quanto Joaquim Azpilicueta e Targino Mariani atuaram em meio a um movimento de trabalhadores que produziu várias outras lideranças sindicais de importância ao longo de toda a República Velha, sendo essas majoritariamente compostas por trabalhadores de origem nacional, fossem eleslocais(amazonenses) ou oriundos de outros estados da federação, notadamente do Nordeste. Anacleto Reis, Cursino Gama, Elesbão do Nascimento Luz, Firmo de Assunção Souza, Hemetério Cabrinha, Joaquim Gomes Evangelista, Manuel Sérvulo, Nicodemos Pacheco e Nicolau Pimentel, apenas para citar os mais destacados, foram alguns dos líderes operários nacionais que se projetaram naquele período. Dessa forma, a ênfase dada aqui às lideranças estrangeiras referenciadas não assume, portanto, nenhuma perspectiva hierarquizadora.

Há que se ter também o cuidado em não idealizar a recepção e participação de militantes e trabalhadores estrangeiros no interior do movimento operário amazonense como marcadas pela assimilação ali de perspectivas do

6 TOLEDO, Edilene. Travessias revolucionárias: Ideias e militantes sindicalistas em São Paulo e na Itália (18901945). Campinas, SP: Editora da UNICAMP, 2004, p. 383-384. 
internacionalismo operário, volta e meia referenciado na imprensa operária, pois como asseverou Marcel van der Linden, "a solidariedade que atravessa as fronteiras nacionais pode parecer lógica, mas não o é na prática".7 Assim, se é possível aceitar a ideia de que militantes como Miranda, Azpilicueta e Mariani encontraram boa acolhida entre os trabalhadores amazonenses, já que, ao fim e ao cabo, foram por eles escolhidos para exercerem em diversas oportunidades a liderança de suas respectivas associações sindicais, nem por isso escaparam das tensões e conflitos étnicos que, como vimos, contaminaram com muita frequência o mundo do trabalho amazonense. Notadamente após 1910, quando a crise da economia de exportação da borracha, trazendo como corolário o desemprego e uma política de arrocho salarial, fragilizou a já combalida condição operária e fomentou velhas e novas dissidências entre os trabalhadores.

Como em outras regiões do país e do mundo, o recurso à contratação de estrangeiros como mecanismo de pressão e reação patronal às demandas e greves animadas pelos trabalhadores locais acirravam os ânimos entre nacionais e estrangeiros, ${ }^{8}$ e isso, por vezes, alcançava lideranças estrangeiras, pondo-as em cheque quanto à capacidade de gerenciamento dos conflitos, produzindo grandes dificuldades organizatórias. ${ }^{9}$

\section{As primeiras lideranças}

A formação tardia e o lento adensamento de trabalhadores na capital amazonense retardaram não apenas o início do processo associativo em Manaus ${ }^{10}$ mas também a formação de lideranças operárias mais expressivas, reconhecidas enquanto tais pelos trabalhadores e atuantes no movimento operário de forma mais intensiva e ostensiva. Essas lideranças parecem ter se estabelecido apenas no final da primeira década do século XX, quando o movimento de trabalhadores urbanos em Manaus dava sinais de crescimento, maior organicidade e disposição para entabular demandas, reivindicações e assumir movimentos de protestos e de luta. Antes desse período, é possível constatar apenas a presença de lideranças de ocasião, entendidas enquanto aquelas formadas e destacadas por movimentos pontuais e efêmeros, quando ainda nem mesmo as agremiações operárias pareciam estar formalizadas. Assim, eclodindo com greves ligeiras e efêmeras, tais lideranças tendiam a logo desaparecer do cenário político sindical e também dos registros documentais.

Maria Luiza Ugarte Pinheiro chamou a atenção, inclusive, para o peso expressivo que demonstraram ter alguns indivíduos que, oriundos do segmento patronal e em vínculo com ele, projetavam-se como lideranças na mediação das primeiras tensões, conflitos e confrontos entre trabalho e capital na cidade da

7 LINDEN, Marcel van der. Trabalhadores do mundo: ensaios para uma história global do trabalho. Trad. Patrícia de Queiróz Carvalho Zimbres. Campinas, SP: Editora da UNICAMP, 2013, p. 291.

8 PINHEIRO, Maria Luiza Ugarte. A cidade sobre os ombros: trabalho e conflito no porto de Manaus (18991925). 3 ed. Manaus: EDUA, 2015, p. 105; 108.

9 FOOT HARDMAN, Francisco; LEONARDI, Victor. História da indústria e do trabalho no Brasil. 2 ed. São Paulo: Ática, 1991.

10 O processo associativo envolvendo trabalhadores da capital amazonense teve início nos anos finais do século XIX com a criação de agremiações como a Sociedade União Beneficente e a Associação Beneficente do Amazonas, ambas de 1897. Associações vinculadas a categorias específicas só apareceram com o início do século XX. Assim foi com categorias específicas, como a Sociedade "Clube União Marítima" (1900), a Sociedade Beneficente União dos Foguistas de Manaus; a Corporação dos Maquinistas do Amazonas e a Sociedade Beneficente dos Práticos no Amazonas, todas de 1906. 
borracha. ${ }^{11}$ Assim ocorreu no primeiro grande movimento paredista da capital amazonense - a greve dos estivadores de 1899 - e ao longo da primeira década do século XX, que finaliza com o aparecimento, em 1909, da primeira proposta de organização de uma confederação dos trabalhadores, organização idealizada e executada com claros interesses patronais pelo coronel Paulino de Brito, importante empresário e intelectual do período.

A fragilidade da organização operária, ainda em seus primeiros passos na capital amazonense, abriu espaço para que os trabalhadores locais sucumbissem a discursos retóricos de "lideranças" que se mostraram de todo desvinculadas e descompromissadas com o mundo do trabalho. Pelos mesmos motivos, não foram poucos os trabalhadores e as associações operárias nascentes que se viram lesadas em ações extorsivas de lideranças recém-chegadas e pouco conhecidas na cidade, como demonstra a crônica jornalística diária da cidade ou as denúncias veiculadas pela imprensa de trabalhadores.

Assim, ganhou vulto a "atuação criminosa" de João Gonçalves Demoniz, também conhecido como Demoniz, que, recém-chegado à cidade, em pouco tempo conseguiu mobilizar algumas categorias para iniciar um processo associativo e de arrecadação de fundos, dando sistemáticos desfalques nas contas dessas entidades. Em pouco tempo, a fraude por ele produzida na Sociedade União dos Marinheiros e Moços ganhou destaque na imprensa e suas práticas, notadamente a de fomentar a criação de associações dissidentes (como entre os estivadores) visando gerenciá-las diretamente, foram fortemente denunciadas em matérias da imprensa operária. O jornal operário A Lucta Social, animado pelo português Tércio Miranda, denunciou também os estelionatos que o mesmo Demoniz havia praticado em Belém, sendo de lá escorraçado pelos operários. As denúncias ocorridas em solo amazonense resultaram no completo banimento de Demoniz das entidades sindicais, desacreditando-o no interior do movimento operário local. Nesse episódio, a reação operária foi de tal monta que, após recorrer à proteção policial, Demoniz viu-se obrigado a retirar-se da cidade.

Bem mais difícil de combater, no entanto, foi a intromissão do patronato no gerenciamento das ações operárias. Em 1909, sob a liderança do espanhol Joaquim Azpilicueta, formou-se um movimento de denúncia do controle patronal estabelecido pela Confederação do Trabalho como extremamente lesivo aos trabalhadores. Por força dessa reação, um denominado "Conselho Supremo da Confederação do Trabalho" deliberou por destituir a direção da entidade, então nas mãos do industrial Paulino de Brito, e emitir nota à sociedade e também ao governador do Estado.

A partir de 1910, foi comum perceber uma reação maior por parte dos trabalhadores amazonenses com relação a lideranças que se mostravam próximas ou que aquiesciam diante dos interesses patronais e em detrimento das demandas sustentadas pela base. Assim, durante a greve de estivadores de 1911, quando a Associação Comercial do Amazonas firma um acordo com Manuel Rufino Correia da Silva, um comerciante português radicado na cidade ${ }^{12}$ que na ocasião presidia a Associação Beneficente dos Estivadores e Carroceiros, o descontentamento grassou entre os trabalhadores e os jornais amazonenses noticiaram que "grevistas mais exaltados... mantiveram-se em atitude ostensiva ao próprio presidente da Sociedade que os protegia...". Recusando o acordo firmado por suas lideranças,

11 PINHEIRO. A cidade sobre os ombros, p. 158.

12 Jornal do Comércio, Manaus, 2 jan. 1911, p. 1. 
os estivadores em assembleia manifestam-se pela continuidade do movimento paredista, pondo em suspeição toda a direção da associação. ${ }^{13}$

Com efeito, o conflito aberto entre as bases operárias e suas respectivas lideranças sindicais nunca foi incomum, e foi fundamentalmente em função de tais contradições que categorias com a dos estivadores - tradicionalmente identificadas no Brasil como vinculadas a sindicatos amarelos - mantiveram em Manaus um histórico de enfrentamento constante com o patronato, em especial com a firma inglesa Manáos Harbour, concessionária dos serviços portuários. Como destacou Pinheiro, numa cidade configurada como entreposto comercial da borracha, as greves portuárias preocupavam seriamente autoridades, comerciantes e casas aviadoras, exatamente por demonstrarem capacidade de parar tanto o porto como, indiretamente, a própria cidade. Movimentos paredistas de estivadores impactaram a cidade em vários momentos ao longo da Primeira República (1899, 1902, 1906, 1911, 1917, 1919, 1923, 1924, 1925), por vezes entabulando três greves num mesmo ano, como ocorreu em 1911. ${ }^{14}$

\section{Negociação, mediação e busca de consenso}

Foi como estivador que o italiano Targino Mariani se estabeleceu em Manaus já no início do século XX, momento em que a dinâmica economia de exportação da borracha atraiu não apenas migrantes nacionais - especialmente nordestinos mas também levas expressivas de estrangeiros, com destaque para portugueses, espanhóis e italianos. Já franceses, ingleses e alemães, por exemplo, aportaram ali em números bem menores, por vezes não ultrapassando algumas dezenas. Em 1907, o médico sanitarista Hermenegildo de Campos, com base no recenseamento de 1900, estabelecia para o conjunto da capital amazonense uma população total de 60.000 habitantes, dos quais pelo menos 10.000 seriam de origem estrangeira:

A maior colônia é a dos portugueses, avaliada por competentes em 5.000; em segundo lugar a dos espanhóis avaliada em 1.400 a 1.500; em terceiro lugar a dos italianos avaliada em 1.100 a 1.200; seguem-se os turcos, árabes, marroquinos, sírios com 800 pessoas; Depois contam-se os naturais de Barbados, em número nunca inferior a 300, sendo em maior quantidade as mulheres empregadas em serviços domésticos. Em número inferior existem os ingleses, cujo número é calculado em 70 a 75. Os franceses não passam de 40. Os súditos alemães não excedem a 50. Seguem-se poucos representantes de outras nacionalidades como peruanos, venezuelanos, colombianos, bolivianos, austríacos, etc. ${ }^{15}$

Samuel Benchimol, um estudioso da presença estrangeira na Amazônia, descreveu a participação de italianos na região, embora enfatizando suas contribuições no campo empresarial e artístico, pouco referenciando o universo do trabalho. ${ }^{16}$ Com efeito, não há como desprezar sua participação, em especial no interior

13 Apud PINHEIRO. A cidade sobre os ombros, p. 215.

14 PINHEIRO. A cidade sobre os ombros, p. 151.

15 CAMPOS, Hermenegildo Lopes de. Climatologia médica do Estado do Amazonas. 2 ed. Manaus: Associação Comercial do Amazonas, 1988, p. 101. Campos sustenta ainda que dos 50.000 nacionais presentes no recenseamento de 1900, pelo menos metade (25.000) era composta por naturais de outros estados. Os oriundos do Ceará eram estimados em 6.690, em 1900, e em 9.000 a 10.000, em 1907.

16 Benchimol argumenta que os italianos em Manaus deram continuidade aos "ofícios que haviam aprendido em seu país", demonstrando "preferência por estabelecimento de vendas de sapato, ourivesaria e oficinas mecânicas". BENCHIMOL, Samuel. Amazônia: Formação Social e Cultural. 3 ed. Manaus: Valer, 2009, p. 452. 
do processo de urbanização modernizadora pelo qual passou a cidade. Em obra recente, Vittorio Capelli buscou relativizar perspectiva historiográfica bastante difundida que tende apresentar uma "Belle Époque amazônica" gestada sobre o duplo impacto do capital inglês e dos projetos urbanísticos e valores estéticos franceses. ${ }^{17}$ Capelli sustenta que em Manaus a marca italiana foi sensivelmente predominante nas artes, na arquitetura e no urbanismo graças à atuação de uma gama de artistas e técnicos oriundos daquele país. ${ }^{18}$

Contudo, é preciso asseverar que, para além de um corpo técnico de profissionais mais qualificados, a grande maioria dos italianos chegados a Manaus engrossou as fileiras da classe trabalhadora, espraiando-se por ofícios diversos, fossem nas oficinas, no comércio ou nas atividades portuárias. Seja como for, parece certo que Targino Mariani vinculou-se a esse grupo de trabalhadores que chegou à cidade sem maiores qualificações. O fato de que em duas décadas de intensa participação na atividade sindical sua fala direta pouco apareça registrada na documentação, seja em termos de discursos proferidos ou em matérias assinadas na imprensa, pode ser tomado como um indicativo de um baixo nível de escolarização e letramento. Bem ao contrário de Mariani, tanto Tércio Miranda quanto Joaquim Azpilicueta registraram continuamente suas impressões, assinando documentos, manifestos, colunas na imprensa operária e na grande imprensa e, no caso de Azpilicueta, também no circuito literário amazonense.

Já mencionamos que, ao contrário dos outros dois militantes estrangeiros, Targino Mariani atuou num espectro bem mais conservador, alinhando-se, portanto, com perspectivas sindicais reformistas que à época mostravam-se hegemônicas entre os trabalhadores amazonenses. Sua atuação política junto ao proletariado amazonense teve início no final da primeira década do século XX, durante o processo de mobilização e discussão de propostas para a criação de um organismo de representação sindical da categoria dos estivadores, processo esse que resultou na criação da União Operária Beneficente Mútua dos Estivadores em 21 de junho de 1908. Tal associação tinha como presidente Eurico Ezell Martins, e trazia o nome de Targino Mariani já numa posição de destaque, atuando ali como seu $1^{\circ}$ secretário. É interessante destacar que nesse momento inicial de organização da categoria o debate sobre as perspectivas político-sindicais ainda se mostrava aberto, permitindo inclusive a discussão sobre a adoção da perspectiva socialista como princípio, como se vê na convocatória assinada por Mariani:

Sociedade União Operária Beneficente Mútua dos Estivadores

Por ordem do Senhor Presidente Eurico Ezell Martins, convido a todos quantos já se inscreveram para sócio-fundador desta sociedade, como a todos os outros que quiserem à mesma pertencer, para uma reunião no domingo 21 do corrente, às 3 horas da tarde, na rua Doutor Moreira, n. 21, afim de tratar de assuntos de real interesse da classe, como na mesma sessão pessoa competente plantará no pensamento de cada um dos assistentes o que é o socialismo.

Targino Mariani, $1^{\circ}$ secretário..$^{19}$

17 DAOU, Ana Maria. Belle Époque amazônica. Rio de Janeiro: Jorge Zahar Editora, 2005.

18 CAPPELLI, Vittorio. La presenza italiana in Amazzonia e nel Nordest del Brasile tra otto e novecento. Rio de Janeiro: Maracanã, 2010, n. 6, pp. 123-146,.

19 Confederação do Trabalho, Manaus, 28 nov. 1909, p. 2. 
Embora não saibamos o teor do debate, a adesão ao socialismo acabou não acontecendo e a associação mostrou-se efêmera, sendo substituída em 26 de junho de 1910 por nova entidade, a Associação Beneficente dos Estivadores e Carroceiros. Desde o momento da formulação de sua primeira associação, as lideranças dos estivadores pautaram-se por perspectivas que condenavam a ação direta e o conflito de classe, e que, em contrapartida, exaltavam os processos de negociação com o patronato, recorrendo muitas vezes à mediação das autoridades públicas na busca de um consenso entre patrões e empregados. Por mais paradoxal que possa parecer, tais perspectivas assumidas tanto por Mariani quanto por outras lideranças dos estivadores não impediram que a categoria, partindo sempre de forte descontentamento das bases, se lançasse a frequentes movimentos paredistas.

Mariani chegou também a participar de movimentos paredistas dos estivadores em 1911, embora sem ocupar posições de grande destaque. Daquele momento até o início da década de 1920, sua presença ficou esmaecida e por vezes seu nome desaparece da documentação, mesmo em momentos de grande agitação e eclosão de greves operárias. Foi apenas na década de 1920 que o nome de Targino Mariani retomou importância, momento em que passou a presidir a organização sindical de sua categoria por quase toda a década. Em 1928, o jornal O Primeiro de Maio, animado por Cursino Gama, o designaria como "um dos mais seguros e valorosos orientadores do Sindicato dos Estivadores do Amazonas".

Com efeito, o papel de Mariani à frente da categoria dos estivadores foi relevante, contribuindo para a estabilidade institucional, já que a trajetória organizativa dos estivadores em Manaus até o final da segunda década do século XX foi extremamente conturbada e suas organizações sindicais resultaram marcadas pela efemeridade, como que perdendo importância após o enfrentamento das demandas pontualmente entabuladas quase sempre voltadas para o valor e a duração da jornada de trabalho. Num certo sentido, assemelhavam-se ao que Marcel van der Linden designou como "organizações cogumelos", sendo essas formadas "ao início ou durante uma greve, e [que] se dissolvem rapidamente após seu término (independentemente de se a greve acaba em vitória, em derrota, ou numa solução de compromisso)". ${ }^{20}$

Seja como for, Targino Mariani foi sem dúvida o principal articulador da reorganização da categoria, quando, em 14 de março de 1920, a antiga Sociedade dos Trabalhadores em Estivas do Amazonas - entidade que havia dirigido a ação dos estivadores por cerca de três anos - foi enfim substituída pelo Sindicato dos Estivadores do Amazonas, com Mariani sendo aclamado presidente.

Com Mariani à frente da nova organização sindical, os estivadores passaram a mobilizar-se de forma mais persistente e conseguem entabular pautas de reivindicações salariais no início de cada ano da década de 1920, em que pese o contexto adverso marcado por forte retração da atividade econômica em toda a região desde o colapso do preço da borracha no mercado mundial. Mesmo assim, ao longo da década, foi comum que nas negociações com as empresas portuárias quase sempre mediadas pela Associação Comercial do Amazonas - a correção das tabelas salariais dos estivadores se efetivassem, mesmo que abaixo das expectativas da categoria. Isso significa que situações de conflito podiam ser deflagradas e, de fato, movimentos paredistas ocorreram em 1923, 1924, 1925, 1927 e 1929.

20 LINDEN. Trabalhadores do mundo, p. 251. Referindo-se ao contexto inglês de fins do século XIX, o autor ainda argumenta que os sindicatos "eram vistos como expedientes temporários destinados a um fim específico. O fim de um sindicato, portanto, era algo esperado assim que seus objetivos tivessem sido alcançados. Uma vida breve era uma de suas características". Idem. 
Analisando as três primeiras greves de estivadores da década de 1920, Pinheiro demonstra a precariedade da organização sindical, dada a correlação de forças mostrar-se desfavorável aos trabalhadores pela crise geral da borracha, trazendo com ela a falência de centenas de firmas (nacionais e estrangeiras) e a retração do comércio, que por sua vez resultava no fechamento de postos de trabalho e em forte desemprego. ${ }^{21}$ Dessa forma, as greves de estivadores ao longo da década foram marcadas tanto por ganhos efêmeros como por dolorosas derrotas em que vigoravam repressão policial e demissões.

O quadro adverso para os trabalhadores expôs também Mariani a processos de contestação e desconfiança por parte de seus próprios pares, insatisfeitos com os resultados dos movimentos paredistas. Assim ocorreu em junho de 1923, quando os estivadores de Manaus retomaram a luta pela jornada de oito horas ${ }^{22}$ sob o argumento de que esse horário já vigorava nos principais portos brasileiros.

Em meio à greve, Mariani assume o risco de negociar com o patronato na sede da Associação Comercial e ali fechar um acordo com a firma inglesa concessionária do porto de Manaus, garantindo a jornada de oito horas, mas com proporcional redução nos vencimentos. Essa opção acabou por mostrar-se desastrosa, já que, recusada pela categoria, produziu o afastamento de Mariani pela dissidência de base, que então assumiu os rumos do movimento, divulgando sua posição pela imprensa local:

\begin{abstract}
Nós, abaixo-assinados, estivadores, protestamos perante a Associação Comercial do Amazonas a resolução tomada em sessão realizada hoje, 07 do corrente, no salão desta mesma associação, pelos senhores Targino Mariani e Joaquim Gomes Evangelista, visto não concordarmos com essa mesma resolução, que sendo por nós aceita venha prejudicarnos em absoluto. Nós pretendemos implantar com todo o ardor as 8 horas; horário este adotado e respeitado em todo o território brasileiro, portanto, brasileiros e portugueses, em ação conjunta, resolvem definitivamente fazer valer nesta capital o horário acima referido, ou então nos manteremos em greve pacífica, caso o comércio em geral, a Manáos Harbour Ltda e a Booth Line não solucionem o caso em apreço. ${ }^{23}$
\end{abstract}

Os dissabores de Targino Mariani perecem ter sido logo contornados, já que é ele quem estará novamente à frente das demandas de sua categoria ao longo dos outros movimentos paredistas daquela década, sendo inclusive eleito e reeleito presidente do Sindicato dos Estivadores em sistemáticas oportunidades, como nos anos de 1928, 1929, 1930 e 1931. Ao se tomar como base informativa a imprensa do período, será possível perceber que esse momento final da década de 1920 marca, para a imagem pública de Mariani, um momento de celebração e de reconhecimento de sua atuação no interior da classe operária amazonense. Um bom exemplo dessa postura celebrativa aparece quando da publicação de seu retrato em 1928 por um periódico da imprensa operária amazonense. ${ }^{24}$

21 PINHEIRO. A cidade sobre os ombros, 202-203.

22 A luta pela jornada de oito horas assumida pelos estivadores amazonenses havia se intensificado desde 1919, quando então a categoria externou seu desejo de que fosse "estabelecido o trabalho diário de oito horas para os estivadores, principiando às 7 horas da manhã e terminando às 5 da tarde, com o intervalo já usado de 2 horas para a refeição, isto é, das 11 às 13 horas". Ata da Associação Comercial do Amazonas, Manaus, 1 jun. 1919.

23 Apud PINHEIRO. A cidade sobre os ombros, 199.

24 O Primeiro de Maio, Manaus, 1 maio 1928, p. 2. 
Figura 1: Targino Mariani

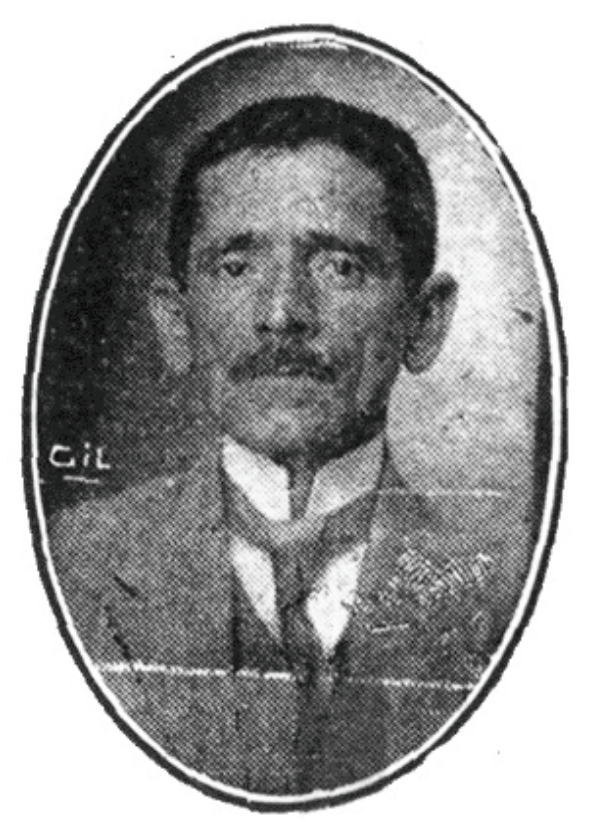

Fonte: O Primeiro de Maio, Manaus, $1^{\circ}$ de maio de 1928.

Assinada por Gil, fotógrafo e artista gráfico que ancorou seu trabalho em diversas revistas e jornais de Manaus, a fotografia de Mariani, assim como a de outras lideranças sindicais amazonenses, é acompanhada em tom celebrativo de retratos do governador do Estado, do prefeito de Manaus e do presidente da Assembleia Legislativa. A distribuição das imagens pelo periódico obedece claramente uma dimensão hierárquica, saindo das autoridades públicas em direção às lideranças da União Operária Amazonense - a quem se ligava o periódico - e dessas para as lideranças de sindicatos e associações vinculados à UOA. Sem forçar em demasia a análise iconográfica, ${ }^{25}$ é possível perceber que a maioria das lideranças sindicais ali homenageadas, incluindo-se Mariani, é apresentada em poses formais, aferidas pelo uso do paletó e da gravata. Além disso, a presença conjunta com as autoridades ajuda a transmitir uma estética de representação que projetava valores como honorabilidade, serenidade e correção, em nada lembrando as dimensões propriamente proletárias e conflitivas que sempre definiram e marcaram os mundos do trabalho.

\section{Contra as dissensões operárias}

Num espectro político-sindical bastante diferenciado, atuaram as outras duas lideranças estrangeiras aqui referenciadas, Joaquim Azpilicueta e Tércio Miranda. Azpilicueta era espanhol, nascido na cidade de Pamplona em 1890, e ingressou no movimento operário amazonense no mesmo período que Mariani, já que em 1909, como acima mencionado, foi ele quem liderou um movimento de base denunciando como lesiva aos trabalhadores amazonenses as ações da entidade patronal Confederação do Trabalho, que então buscava orientar as ações operárias na cidade. ${ }^{26}$

25 KOSSOY, Boris. Fotografia \& História. 2 ed. São Paulo: Ateliê Editorial, 2001, p. 118.

26 Sobre essa entidade patronal, convém consultar o periódico homônimo por ela veiculado em 1909. A Confederação do Trabalho, Manaus, 14 nov. 1909. 
Por força de sua participação na imprensa local - era tipógrafo, mas atuou também como jornalista assinando várias matérias ao longo de toda sua vida -, é possível perceber sua presença em Manaus já em 1905, atuando como "hábil compositor tipográfico", segundo nota do Jornal do Comércio. ${ }^{27}$ No ano seguinte, aparecem referências que indicam estar casado com a também espanhola Gregória Ortega Azpilicueta, que ofertava seus serviços de bordadeira ("a ouro, branco e seda") e também de professora particular, atendendo em "casas de família" e no Colégio Francês. ${ }^{28}$

O primeiro artigo que encontramos da lavra de Joaquim Azpilicueta data, na verdade, do ano anterior e era intitulado de "Politica Española". Chama a atenção o fato do artigo ter sido publicado em espanhol, denunciando um contato ainda pequeno do autor com a língua portuguesa. O mais importante, no entanto, é que nesse artigo o jovem imigrante esboçava críticas severas à política e ao governo espanhol, enquanto demonstra seus vínculos com temas e questões que o marcarão pelo resto da vida. Nesse sentido, a análise da conjuntura por ele desenvolvida não esquecerá de denunciar que "el proletariado español muere de hambre". ${ }^{29} \mathrm{Em}$ outra ocasião, quando do atentado contra o rei Afonso XIII, Azpilicueta faz publicar novo artigo em que condena o ocorrido, chamando-o de "odioso atentado", mas aproveita para explicitar algumas de suas posições políticas quando se apresenta como "enemigo acérrimo de las actuales instituciones de mi querida patria, adversario intransigente de la monarquía española, no he vacilado nunca en atacarla en cuantas ocasiones he encontrado propicias". ${ }^{30}$

O pouco domínio do português não o impediu de projetar-se, desde logo, no cenário jornalístico amazonense e, dessa forma, já em junho de 1906, apareceria como redator do recém-lançado La Union, periódico que se apresentava como representante da pequena comunidade peruana radicada em Manaus, que vinha sendo dinamizada pela expansão da borracha na Amazônia e pelo consequente desenvolvimento do comércio em lquitos, que passou a interagir mais intensamente com a praça de Manaus. O contato de Azpilicueta com o La Union foi, contudo, estranhamente rápido, não demorando mais de um mês, o que nos leva a pensar que mais que o domínio da língua espanhola, critérios de nacionalidade tenham sido percebidos como necessários para um órgão que se projetava como representante de uma comunidade específica. Infelizmente, nem a notificação de seu afastamento, publicada pelo Jornal do Comércio, nem o próprio La Union esclareceram os motivos.

Convém asseverar que a atuação jornalística de Azpilicueta se fazia em paralelo à sua atuação profissional de compositor tipográfico, atuando inicialmente no jornal A Notícia e posteriormente em outros diários da capital amazonense. Sua militância política voltou-se inicialmente para a mobilização da comunidade de seu país radicada em Manaus, resultando desse engajamento a criação da Sociedade Espanhola Beneficente em novembro de 1908. Nela, Azpilicueta passou a ocupar o cargo de secretário, função que por vezes o projetou como orador não apenas nas festividades e eventos da comunidade espanhola como também nas manifestações operárias. Coube a ele, por exemplo, o papel de orador principal em evento que se organizou em Manaus, em fins de 1909, para denunciar o assassinato de Francisco Ferrer, momento em que suas posições políticas alinhadas ao socialismo já pareciam estar definidas. ${ }^{31}$

27 Jornal do Comércio, Manaus, 30 ago. 1906, p. 1.

28 Jornal do Comércio, Manaus, 22 maio 1906, p.2.

29 Jornal do Comércio, Manaus, 18 maio 1905, p. 1.

30 Jornal do Comércio, Manaus, 3 jun. 1906, p. 2.

31 Jornal do Comércio, Manaus, 25 out. 1909, p.1. 
Alvo de profundas críticas por parte de militantes anarquistas e socialistas que atuavam na cidade, as associações beneficentes eram apontadas como um dos grandes problemas limitadores de uma ação de maior combatividade do operariado amazonense, e, nesse sentido, o papel de Azpilicueta, assim como de Tércio Miranda, foi importante, defendendo, sem rodeios, a assimilação de orientações revolucionárias para a ação da classe operária amazonense. Esse posicionamento pode ser percebido em agosto de 1910, quando das reuniões preparatórias visando a organização da categoria dos motoristas e condutores. Durante os debates, José de Calazans defendeu que o "sistema da associação" fosse o "sindicalismo adotado pela Confederação Geral dos Trabalhadores da França". ${ }^{22}$ A proposta contou com o apoio de Azpilicueta, embora ele se perfilasse de forma explícita, como adiante se verá, pelo que designava como "Socialismo de Estado".

É digno de nota o fato da convocatória para a reunião conclamar "todas as classes manuais, sem distinção de nacionalidade", demonstrando que havia tensões entre trabalhadores nacionais e estrangeiros ${ }^{33}$ que precisavam ser vencidas em prol da organização da categoria, como de resto pensavam muitos dos principais líderes operários amazonenses, evocando o internacionalismo da classe operária. A ponderação era válida não apenas porque em Manaus, como em outros lugares, parte significativa da classe operária tendeu a identificar-se prioritariamente a partir de suas identidades étnicas, vinculando-se a agremiações (mutualistas, beneficentes, repatriadoras, etc.) que voltavam suas atenções aos segmentos étnicos específicos, fossem portugueses, espanhóis, peruanos, ou mesmo cearenses.

Em Manaus, comunidades diaspóricas ${ }^{34}$ se organizaram precocemente, ainda em fins do século XIX, momento em que associações por categorias profissionais ainda não haviam se estruturado na cidade. Organizar-se nesse tipo de associação respondia a uma gama enorme de questões que se colocavam como problemas efetivos. Em primeiro lugar, externava tanto o desejo de responder aos dilemas da adaptação ao inóspito ambiente amazônico - particularmente no caso dos trabalhadores deslocados para os seringais de rios como o Madeira, o Juruá ou Purus - quanto às asperezas das relações de um ambiente citadino crivado de segmentações excludentes e de preconceitos diversos contra migrantes de uma forma geral. Em segundo lugar, significava ainda criar mecanismos de reação ao insucesso na inserção no mundo do trabalho, cada vez mais competitivo e restrito após a crise da borracha em 1910. Por fim, as associações de comunidades étnicas respondiam também ao desejo do migrante de ver-se conectado às suas origens nacionais, comunitárias e familiares, buscando recriar, por meio da organização de festas, atividades esportivas e de recreação, uma ambiência social e cultural que mantivesse vivas e reafirmasse suas identidades nacionais ${ }^{35}$ e/ou regionais.

32 Jornal do Comércio, Manaus, 30 ago. 1910, p. 2. Argumentando que as diversas correntes que atuavam no movimento operário brasileiro da República Velha tenderam a buscar "'modelos' justificadores e legitimadores" de suas posições, Cláudio Batalha associa a CGT francesa com os que no Brasil pugnavam pela ação direta e tinham por inspiração o sindicalismo revolucionário. BATALHA, Cláudio. "Identidade da classe operária no Brasil (1880-1920): atipicidade ou legitimidade?" Revista Brasileira de História, São Paulo, v. 12, n. 23-24, set. 1991/ago. 1992, p. 111-124.

33 Por vezes as tensões afloravam de forma mais intensa, desembocando em conflito aberto, como ocorreu em 1914, após um jornal de Manaus circular telegrama denunciando que "carbonários portugueses haviam espatifado a bandeira brasileira e insultado o nosso país". Amazonas, Manaus, 28 set. 1914.

34 O termo é aqui empregado a partir do sentido que The atribui Bela Feldman-Bianco, utilizando-o "metaforicamente para descrever, de forma genérica, pertencimento e identificação além-fronteiras nacionais, independente da ligação ou não a Estados Nacionais". FELDMAN-BIANCO, Bela. Nações e diásporas: estudos comparativos entre Brasil e Portugal. Campinas, SP: Editora da UNICAMP, 2010, p. 15.

35 ANDERSON, Benedict. Comunidades imaginadas: reflexões sobre a origem e a difusão do nacionalismo. São Paulo: Cia das Letras, 2008, p. 34; 65-70. 
Nesse processo a imprensa desempenhou um papel destacado, projetando-se tanto como mediadora quanto como articuladora de tais vínculos, no mesmo momento em que buscava traduzir, no ambiente local de sua inserção, a "voz" da comunidade. Não foi à toa que portugueses, ${ }^{36}$ espanhóis, ingleses e peruanos produziram em Manaus algumas dezenas de periódicos com essas características. ${ }^{37}$

A consciência de que a vinculação dos imigrantes estrangeiros a organizações mobilizadas exclusivamente por critérios atinentes à etnicidade prejudicava o processo associativo da classe trabalhadora estava presente em algumas lideranças operárias que atuaram em Manaus, sendo Joaquim Azpilicueta, nesse particular, um dos mais destacados. Seguramente por isso, assumiu postura dissidente com relação à iniciativa de seus conterrâneos de criar em Manaus um "Centro Socialista de Espanhóis". Na reunião, que contou com aproximadamente 200 espanhóis, Azpilicueta foi voto vencido e seu nome não consta entre os membros encarregados de escrever a proposta na nova associação. ${ }^{38}$

Adotando sempre um tom mais conciliador, mas sem abrir mão de suas convicções, Azpilicueta foi personagem destacado no debate e nas ações que em Manaus levaram os gráficos a assumir uma posição de destaque no movimento operário a partir de 1913. Foi ele quem presidiu a assembleia geral da categoria quando esta começou a preparar sua reestrutura como agremiação sindical, em substituição à Sociedade das Artes Gráficas do Amazonas, que havia sido criada em outubro de 1910.

Sem descuidar de seu envolvimento com a ação direta, já que era defensor do processo de sindicalização e da greve como mecanismo de luta e de transformação social, Azpilicueta salientou por diversas vezes sua perspectiva socialista, notadamente quando de seu envolvimento com o processo político partidário, empenhando-se em campanhas para que o operariado amazonense elegesse um representante da classe trabalhadora. Assim ocorreu, por exemplo, quando defendeu em notas pela imprensa a eleição do tipógrafo Theodorito de Brito nas eleições municipais de novembro de 1913. Nesse caso em particular, chama a atenção o fato de o abaixo-assinado veiculado pela imprensa diária de Manaus iniciar demarcando os signatários como "cidadãos brasileiros [...] em pleno exercício de seus direitos civis e políticos". Não parece, contudo, ter sido o caso de Joaquim Azpilicueta. ${ }^{39}$

Já no campo da ação direta, assim como Tércio Miranda, Azpilicueta foi também partícipe do maior e mais importante movimento paredista realizado pelos trabalhadores gráficos em Manaus, resultando num enfrentamento direto e radical contra o patronato dos maiores diários locais. Após vários dias de tensão, com dissidências e forte repressão policial, a greve dos gráficos fracassou, dando vazão a uma onda de perseguições e demissões. A visão dos acontecimentos produzida tanto por Joaquim Azpilicueta quanto por Tércio Miranda e demais lideranças dos gráficos aparece melhor demarcada em dois periódicos operários da cidade, A União e A Lucta Social, que se esmeraram em descrever a situação de penúria dos trabalhadores e a intransigência patronal:

36 PINHEIRO, Geraldo. Imprensa, política e etnicidade: portugueses letrados na Amazônia (1885-1933). Doutorado em História. Universidade do Porto (Portugal), 2012.

37 FREIRE, José Ribamar Bessa (Coord.). Cem anos de imprensa no Amazonas (1851-1950): catálogo de jornais. Manaus: Editora Calderaro, 1990.

38 Jornal do Comércio, Manaus, 29 jun. 1914.

39 Jornal do Comércio, Manaus, 5 out. 1913. 
Há já bastantes dias os operários gráficos de "O Tempo" diariamente publicado nesta cidade, se declararam em greve pacífica. Segundo fomos informados, a falta de pagamento aos operários motivou o levante. Havia cinco semanas que os escravos daquele órgão não tinham o prazer de contemplar o gorro frígio dum níquel. O padeiro à porta, o proprietário amável como sempre ameaçava com despejo; a carne a 1500 e 1700; (ainda dizem que há crise) o merceeiro suspendera o crédito, o calçado gasto, e... enfim pelo esôfago só passava (às vezes) um café, água quente em direção do estômago - é singular. Como sanar esse mal?... Era quase impossível. O caso é que os gráficos d’O Tempo já não podiam resistir à Sra. Miséria. ${ }^{40}$

Nas páginas do A Luta Social foi também possível perceber um debate, embora sutil e elegantemente estabelecido, entre concepções diferenciadas da luta operária. Com efeito, o jornal adquiriu característica de verdadeiro campo de batalha ideológico, de onde a orientação sindicalista revolucionária adotada por Miranda identificava como alvo prioritário de suas críticas as organizações operárias vinculadas a perspectivas reformistas e conservadoras, "aferradas ao tronco da beneficência". A fala de Miranda, sempre enfática como se verá adiante, alcançava também a ação de agremiações e lideranças que militavam em outros espectros ideológicos, do mutualismo ao socialismo, e talvez seja essa a razão da intervenção feita por Azpilicueta em matéria assinada no terceiro número daquele periódico. Sua fala também permite perceber o caldeirão em que havia se transformado o debate ideológico na capital amazonense:

Sou completamente contrário à luta entre os operários, porque entendo que essa luta é inglória, prejudicial e contraproducente, ante os fins que perseguimos, pois que com discussões de certo gênero só damos ares aos elementos que devemos combater.

Sou completamente solidário com todos os que queiram concorrer à futura transformação social, dentro da evolução, chamem-se socialistas de Estado - grupo a que pertenço -, coletivistas ou sindicalistas.

Precisamente aqui no Amazonas temos grande campo para propagar o socialismo, devido ao grande descuido com que os poderes públicos tratam o proletariado. (...)

Agora bem: ante essa precária situação que estamos passando todos... não é triste esse espetáculo que, consciente ou inconscientemente, estão dando, para gáudio dos burgueses, esses nossos companheiros..., dando mal exemplo, lançando odiosidades extemporâneas.

Não, não é esse o caminho a seguir.

Formemos fileiras estreitas, unidas, para defender os nossos direitos, sem esquecer os nossos deveres.

Sejamos também firmes e compactos para procurar a união de todo o proletariado, educando-o, propagando as doutrinas sãs e benéficas do puro socialismo.

Acabemos com essas dissensões e, unidos, batalhemos em prol dos espoliados e contra os exploradores. ${ }^{41}$

O chamamento à união proposto por Azpilicueta, e o fato de tê-lo feito pelas páginas de um periódico animado por perspectiva ideológica diferenciada (o sindicalismo revolucionário), parece dar razão à perspectiva assumida por

40 A Lucta Social, Manaus, 29 mar. 1914.

41 A Lucta Social, Manaus, $1^{\circ}$ jun. 1914. 
Isabel Bilhão quando da análise do complexo relacionamento entre lideranças e tendências do movimento operário de Porto Alegre da primeira década do século $\mathrm{XX}$, momento em que a autora defende a ideia de que: "Por mais que insistam nas diferenças ideológicas que os distanciam, os grupos que disputam a direção do movimento operário porto-alegrense têm, na prática, muito mais pontos em comum do que divergências". 42

Após o movimento paredista de 1914, a presença de Azpilicueta no interior do movimento operário local parece esmaecer, assim como a força política de sua categoria. Continuará ele, todavia, a expressar-se no campo das letras e na atividade jornalística, assinando matérias de conteúdos diversos e produzindo literatura. Não abandonou de todo a militância operária, já que foi possível encontrá-lo, na década de 1920, vinculado à União Operária Amazonense (UOA), órgão que estruturou majoritariamente a luta operária em Manaus até o início dos anos 1930. ${ }^{43}$

\section{Tércio Miranda}

O terceiro e último dos militantes estrangeiros aqui referenciado é Tércio Miranda, com quem Azpilicueta manteve estreita e colaborativa relação entre 1913 e 1915. Natural de Amarantes (Portugal), Tércio chegou a Manaus em fins de 1912, contando 24 anos de idade. ${ }^{44}$ Já no início do ano seguinte, iniciaria forte militância na cidade, tornando-se ali uma das mais importantes lideranças estrangeiras entre os trabalhadores amazonenses.

De forma contrária a Targino Mariani e Joaquim Azpilicueta, Miranda chega a Manaus já maduro e com profissão definida ("gravador"), trazendo na bagagem uma trajetória político-sindical já iniciada em Portugal e que estava vinculada a perspectivas revolucionárias, tendo ele se envolvido, de acordo com Luciano Costa, "com o Anarquismo", participando no Porto (Portugal) do grupo Aurora Social, onde também "liderou a Liga D’Educação Nova, em 1912".45

Sua chegada a Manaus coincide com um momento de grande efervescência no ambiente operário e também de agitação popular provocada pela crise da borracha e por ações espoliativas assumidas pelas firmas estrangeiras concessionárias dos serviços públicos de água, luz, transporte e abastecimento de víveres. ${ }^{46}$ Quando se associa ao movimento organizativo dos gráficos de Manaus, esses pareciam apresentar uma situação diferenciada da imensa maioria dos trabalhadores amazonenses, seja porque haviam conseguido sindicalizar a quase totalidade dos profissionais do ofício que atuavam nos jornais amazonenses, seja, ainda, e principalmente, por sua aproximação mais pontual com os ideais revolucionários.

42 BILHÃO, Isabel. Rivalidades e solidariedades no movimento operário (Porto Alegre, 1906-1911). Porto Alegre: EDIPUCRS, 1999, p. 109-110.

43 Embora a criação da UOA date de 1918, o vínculo de Azpilicueta a ela só ocorreu em 8 de janeiro de 1925.

44 Tércio Miranda nasceu no dia 27 de janeiro de 1888 , sendo filho de Manuel Fernandes da Silva. O processo com seu pedido de emigração para Manaus encontra-se no Arquivo Distrital do Porto (Portugal) e é datado de 9 de outubro de 1912, data também da emissão de seu passaporte $\left(n^{\circ} 858\right)$.

45 COSTA, Luciano Everton Teles da. "O desmontar do velho castelo: o jornal A Lucta Social e a adesão à rebelião tenentista de 1924, em Manaus". Oficina do Historiador, Porto Alegre, EDIPUCRS, v. 9, n. 1, jan./jun. 2016, p. 79-80.

46 Em meados de 1913, durante a administração de Jonathas Pedrosa, e, portanto, em plena crise da borracha, a deliberação de algumas firmas estrangeiras de cortar as ligações de água e luz como resposta à forte inadimplência que se estabeleceu na cidade resultou em protestos violentos, com os populares atacando e incendiando algumas sedes dessas empresas. 
Com efeito, os gráficos foram pioneiros em Manaus na estruturação dos sindicatos, em meio a um processo associativo fortemente marcado por perspectivas reformistas alinhadas a organizações mutualistas e beneficentes. Com a implementação do sindicato, os gráficos propõem a reorganização dos trabalhadores amazonenses em novas bases, com parte significativa de seus membros abraçando de forma clara o sindicalismo revolucionário, tendência que, de acordo com Linden, atuou em todos os continentes entre 1890 e 1940 e via "o conflito entre trabalhadores e empregados como uma 'guerra de classes". 47

Nesse mesmo momento (1913), a linha organizacional assumida pelos gráficos no Amazonas passa a se aproximar da Confederação Operária Brasileira (COB), mantendo, inclusive, um representante seu (Rosendo dos Santos) no segundo congresso daquela confederação. ${ }^{48} \mathrm{~A}$ presença de representantes amazonenses no Congresso da $\mathrm{COB}$ era a confirmação de que os ideais do sindicalismo revolucionário circularam e fizeram adeptos no Amazonas, embora poucos registros apareçam na documentação do período. Convém esclarecer que, como em outros lugares, foi comum que a própria documentação de época incorresse em imprecisão, utilizando terminologias importantes de forma bastante genérica. Assim, na imprensa amazonense do período, por exemplo, o termo anarquismo foi mais comumente empregado para designar o radicalismo e as ações violentas que apareciam no seio da classe operária. De qualquer forma, mesmo que os vínculos ideológicos não apareçam textualmente indicados nas fontes, podem, todavia, se inscrever nas práticas, nas ações dos trabalhadores. Assim, quando, na madrugada do dia 5 de junho de 1911, dois estivadores da Manáos Harbour fizeram explodir uma dinamite no portão da empresa, a imprensa e o chefe de polícia por ela ouvido empregam indistintamente os termos vândalos e anarquistas. 49

Seja como for, a chegada de Tércio Miranda a Manaus impactou de imediato o movimento associativo dos gráficos, organizados no início de 1913 em torno da Sociedade das Artes Gráficas do Amazonas, tendo Miranda assumido logo o cargo de secretário-geral da instituição. No ano seguinte, os gráficos estruturam nova associação, já com o nome de Sindicato dos Trabalhadores Gráficos do Amazonas, cuja direção estava entregue, em 19 de julho de 1914, a uma comissão administrativa provisória composta por Tércio Miranda, Domingos Batista Guedes, Joaquim Azpilicueta, Antônio Dias Martins e Ananias Linhares da Silva. ${ }^{50}$

A passagem de Miranda por Manaus é rápida (1912-1915), mas impactante. As primeiras informações sobre ele na imprensa local remontam ao início de 1913, momento em que foi contratado pelo Jornal do Comércio para nele montar um

47 LINDEN. Trabalhadores do mundo, p. 252. No Brasil, Edilene Toledo tem apontado o sindicalismo revolucionário como "corrente política autônoma em relação ao anarquismo e ao socialismo", constituindose "num movimento internacional que tinha como base a defesa da luta de classes, da ação direta dos trabalhadores, da autonomia operária e da neutralidade política dos sindicatos". TOLEDO. Travessias revolucionárias, p. 21. O tema é, contudo, controverso, acolhendo interpretações diferenciadas de parte da historiografia do trabalho: SAMIS, Alexandre. "Pavilhão negro sobre pátria oliva". In: COLOMBO, Eduardo et al. História do Movimento Operário Revolucionário. São Paulo: Imaginário; São Caetano do Sul: Imes, 2004; OLIVEIRA, Tiago Bernardon de. "Anarquismo, sindicatos e revolução no Brasil (1906-1936)". (Tese de doutorado em História. Niterói: Universidade Federal Fluminense, 2009).

48 A Voz do Trabalhador, Rio de Janeiro, 1913.

49 Jornal do Comércio. Manaus, 6 jun. 1911, p. 2. Após investigação policial, a denúncia resultou falsa e falaciosa, não passando de uma tentativa do jornal de retaliar seus antigos funcionários gráficos, caracterizados tanto pelo radicalismo quanto pela prevalência, entre eles - e em especial entre suas lideranças - de trabalhadores portugueses. A União, Manaus, 29 set. 1914, p. 1.

50 A Lucta Social, n. 4. Manaus, $1^{\circ}$ set. 1914. O periódico também informa sobre os estatutos da nova agremiação, por onde se percebe a aceitação do "pacto social estatuído na C.O.B. (Confederação Operária Brasileira)", embora manifestem-se contrários a qualquer escola política ou religiosa e ao princípio eletivo, sendo os seus cargos escolhidos sempre por aclamação da assembleia geral. 
laboratório - um "ateliê de fotogravura e zincografia" -, sendo o responsável por fazer estampar "instantâneos" colhidos pelas ruas da cidade. A se levar em conta a apresentação que dele faz o jornal, Tércio não seria, portanto, um mero clicherista, mas alguém que estava bem informado e na vanguarda da técnica de transposição da fotografia para suporte jornal, algo até então inédito no Amazonas.

\section{Imagem 2: Tércio Miranda em seu Ateliê}

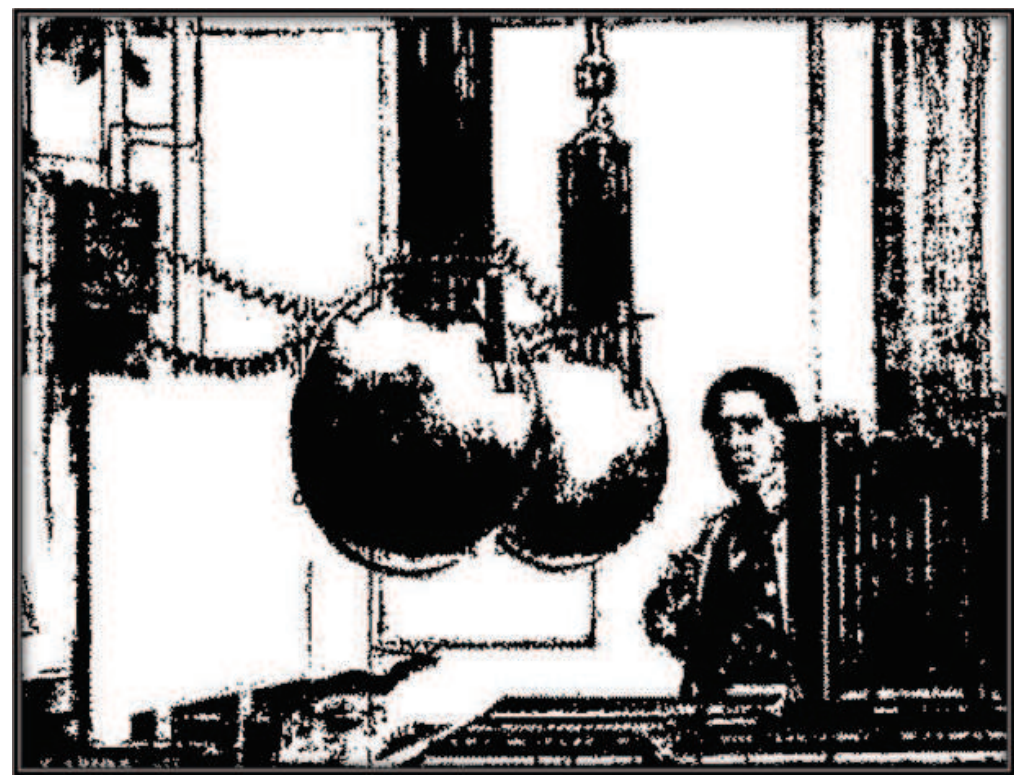

Fonte: Jornal do Comércio, Manaus, 2 jan. 1913.

O jornal, que em edição comemorativa de sua primeira década já havia estampado uma fotografia de Miranda, o menciona também como "afamado artista gráfico", descrevendo-o em termos bastante lisonjeiros: "Artista amante de sua arte, a quem consagra uma dedicação sem limites, Tércio há criado em torno de sua pessoa um círculo de admiração entusiástica. Cavalheiro de fino trato, tem feito a cada um de nós um amigo dedicado, que o quer com verdadeira afeição". ${ }^{51} \mathrm{~A}$ imagem impressa na edição comemorativa incorpora ao texto uma agregação de valor que busca exaltar não apenas o profissional recém-contratado, como também a modernidade e a sofisticação tecnológica alcançada pelo próprio jornal, fazendo com que, na fotografia, Tércio seja representado como um artista confiante e zeloso, que, todavia, partilha seu talento e respeito com o laboratório e equipamentos que o circundam e lhe servem de moldura.

Em que pese os elogios recebidos, a relação amistosa de Miranda com seus empregadores não durará muito tempo, em especial pelo papel importante que o militante português desempenhará na deflagração e condução da greve dos gráficos ocorrida no final de 1913. O movimento havia se iniciado entre os trabalhadores do jornal Amazonas, ${ }^{52}$ que recorreram à intervenção do sindicato, recebendo dele o apoio incondicional. Como os próprios gráficos indicaram, foi graças à intervenção de Tércio como principal ator do processo de negociação que o movimento ganhou densidade e se espraiou para outros órgãos da imprensa amazonense. ${ }^{53}$

51 Jornal do Comércio, Manaus, 27 jan. 1913.

52 Em outra importante greve, no início de 1914, foram os trabalhadores do jornal O Tempo que iniciaram o movimento, recebendo igual apoio sindical.

53 A União, n. 1. Manaus, 26 set. 1914. 
Desde cedo a atenção de Tércio Miranda havia se voltado para a necessidade de ampliar a base de apoio sindical, dotando os trabalhadores de informação e formação política, sendo essa a principal motivação que o impulsionou em direção à dinamização de uma imprensa de e para os trabalhadores. Seus vínculos com o sindicalismo revolucionário o haviam colocado em contato com a Confederação Operária Brasileira, que desde o congresso de 1913 vinha fomentando a expansão da doutrina sindicalista por todo o Brasil, em especial por meio da produção e difusão de jornais, peças estratégicas no processo de formação e conscientização da classe operária. Naquela ocasião, reverberando as propostas e posicionamentos da COB, o jornal A Voz do Trabalhador esclarecia tal percepção:

\begin{abstract}
Uma das principais deliberações do Segundo Congresso Operário Brasileiro está sendo levada à prática. Referimo-nos à resolução tomada pelos congressistas sobre a necessidade imprescindível que há para as associações operárias de manterem os seus jornais, a fim de despertar o espírito de luta entre os seus associados.

Não se pode negar o grande valor que tem a palavra escrita, fazendo brotar ideias e robustecendo a mentalidade operária. O jornal, por outro lado, é o melhor veículo das ideias de transformação social.

É, pois, com grande satisfação que constatamos o fato de já terem alguns sindicatos tomado na devida consideração este acordo do Segundo Congresso, tornando-o uma realidade. ${ }^{54}$
\end{abstract}

No Amazonas, essa tarefa foi prontamente assumida pelo Sindicato dos Trabalhadores Gráficos que, de acordo com Pinheiro, teria escolhido inicialmente o formato de boletim para seu impresso, por ser esse formato mais barato, de simples impressão e de maior difusão. A autora também informa que "naquele formato, apenas dois números foram produzidos, embora nenhum deles pareça ter sido preservado".55 O passo seguinte foi a tomada de decisão de editar em Manaus um jornal na linha do sindicalismo revolucionário assumido pela $C O B$, recebendo esse periódico a denominação de A Lucta Social. Datada do início de março de 1914, uma carta de Tércio de Miranda à COB expondo tal decisão e os objetivos traçados para o empreendimento foi também divulgada pelo $A$ Voz do Trabalhador:

É posto em circulação no próximo dia 29 um jornal para a propaganda do operariado. A sua publicação é feita por um grupo de camaradas, que só agora acham própria a sua saída. Oxalá que nesta terra o operariado, que tem sido refratário à sua verdadeira organização, o saiba receber como é necessário. E que, com sinceridade e consciência, os orientadores das sociedades até aqui aferradas ao tronco da beneficência, saibam, nos seus organismos, fazer sentir a sua ação reformadora, moldada em fórmulas puramente libertárias. ${ }^{56}$

O jornal operário amazonense veio à luz no dia 29 de março de 1914, apresentandose como "órgão operário livre" e identificando como público alvo, "o conjunto dos operários amazonenses". Externando seu programa, perfila-se ao lado do

54 A Voz do Trabalhador, n. 47. Rio de Janeiro, 15 jan. 1914.

55 PINHEIRO, Maria Luiza Ugarte. Folhas do Norte: Letramento e periodismo no Amazonas (1880-1930). Manaus: EDUA, 2015, p. 196.

56 A Voz do Trabalhador, Rio de Janeiro, $1^{\circ}$ maio 1914. Após a transcrição da carta, o jornal empenhava seu apoio: "Para o novo paladino pedimos o interesse do operariado consciente, podendo quem desejar dirigir-se a Tércio Miranda, caixa postal 78, Manaus". 
proletariado e indica com precisão seus alvos e adversários no estado, que o jornal aponta ser "preconceituoso":

Vamos tentar fundar, com uma grande ajuda, que é a nossa boa vontade, um jornal operário com o título que epigrafa essas linhas.

Sendo de orientação operária, todos percebem que é um jornal pronto e apto a defender o pequeno, o humilde, o produtor, contra o burguês enfatuado, esnobista e mal cheiroso.

$\cdots$

Este jornal é operário, e como tal, bastante justiceiro. ${ }^{57}$

Talvez a característica mais importante e singular do A Lucta Social no contexto da imprensa operária amazonense tenha sido a de assumir um claro projeto de formação política a partir da discussão pedagógica de temas e questões centrais à condição e à causa operária. O "salariato", a luta de classes, a consciência operária, os sindicatos operários, a greve, a liberdade e a própria luta social são temas que aparecem em suas colunas. Acima de tudo, tais termos são ali apresentados como categorias-chaves que estruturam e orientam a condição e a luta operária. ${ }^{58}$

Muitos desses textos são reproduções do pensamento de autores libertários, como Kropotkine, Eliseu Reclus, Emile Pouget, José Prat ou Anselmo Lorenzo. Outros são destinados à exaltação de pensadores libertários, como Francisco Ferrer e Gustave Hervé. Além desses textos, alguns colaboradores assinam matérias sobre o movimento operário e outros temas locais usando pseudônimos bastante vagos, como Dido, Annaiv e Zed Nánref. Esses dois últimos referemse, provavelmente, a Fernandez Varela e Vianna que, assim como Miranda, eram dirigentes do Sindicato dos Gráficos do Amazonas.

Como acima mencionado, Miranda utilizou largamente o jornal para atacar a orientação hegemônica no interior do movimento operário amazonense (a "beneficência"), que ele via como prejudicial à emancipação operária. Por outro lado, pela coluna "movimento social" podia-se também acompanhar a trajetória organizativa que, inversamente, se direciona para perspectivas do sindicalismo revolucionário, como vinha ocorrendo commarítimos, choferes, carroceiros, boleeiros e alfaiates, além dos práticos, a quem o jornal exalta como exemplo de categoria a avançar na consciência operária: "Tinham esses camaradas duas sociedades em que se dividiam. Pois bem: a consciência na solidariedade se manifestou, unindo as duas numa só; e na ação social, a consciência transparece na abolição de beneficência esse cancro que é preciso desaparecer das sociedades operárias". .9

Pelo A Lucta Social, Miranda criticou também o cooperativismo, alegando ser inócuo e subordinar os trabalhadores aos favores tanto de patrões quanto do Estado. Em resposta, tanto às associações beneficentes quanto ao cooperativismo, propunha, sem rodeios, que "é com o movimento de classe, com o nome significativo de sindicalismo, que o operariado se tem mancomunado na conquista de melhor salário e de menos horas de trabalho". ${ }^{60}$

57 A Lucta Social, $\mathrm{n}^{\circ}$ 1. Manaus, 29 mar. 1914.

58 Para os editores do A Lucta Social, "o operariado não precisava de esmolar a proteção de quem quer que seja; mas, estudar os problemas da vida e organizar a campanha em favor de sua emancipação". A Lucta Social, Manaus, $1^{\circ}$ jun. 1914.

59 A Lucta Social, Manaus, 29 mar. 1914.

60 Idem. Um debate paralelo e igualmente importante no interior do A Lucta Social dizia respeito às 
O jornal prosseguiu sua cruzada até $1^{\circ}$ de novembro de 1914, momento em que saiu seu sexto eúltimo número, voltado principalmente para a avaliação do fracasso da greve dos gráficos do jornal Amazonas, para notícias sobre a situação política em Portugal - pátria de origem de muitos gráficos que atuavam no Amazonas - e para uma condenação veemente da guerra, apresentada por Miranda no jornal como um conflito burguês e imperialista, da qual o proletariado deveria se recusar a participar. Com efeito, em "Carta aberta a meu irmão", Tércio Miranda fazia um dramático apelo à resistência operária diante do conflito, chegando a sugerir até mesmo a deserção ante o imperativo da convocação para o front de batalha:

\begin{abstract}
Obrigado pelas "forças legais", não vás. Não és militar. E eu nunca me arrependerei de ter conseguido tal. Porém, a força arbitrária pode obrigar-te. Não vás, meu irmão. Não procures matar, fazer mal àqueles que, não sendo teus irmãos como eu, pertencem, todavia, à fraternal família humana. E tu tens uma esposa que ficaria em pranto e um filhinho que deixarias abandonado. Aceita antes o suicídio, porque eu prefiro tirar uma vingança, a chorar eternamente a tua vida de bandoleiro do Estado. Morre por um ideal, mas não por uma ambição criminosa.
\end{abstract}

Prefere a perseguição dum mártir, aos louros dum herói: este é um assassino ou um ladrão, aquele é simplesmente um justo. ${ }^{61}$

Se o alvo primário era seu irmão Abílio, sua fala alcançava também a numerosa colônia portuguesa radicada em Manaus da qual fazia parte, como muitos de seus companheiros. O último número do jornal, previsto para sair em 13 de outubro com uma homenagem a Francisco Ferrer, teve sua saída atrasada por força de um acidente sofrido por Tércio Miranda que, ainda em $1^{\circ}$ de novembro - data da saída do jornal - continuava acamado. Previa-se também a saída de uma próxima edição, a de número sete, "logo que aquele companheiro possa sair de casa, pois, conforme o seu desejo, deve o nosso jornal ser ilustrado com um retrato de Ferrer, cuja execução ele há de concluir". ${ }^{62}$

O número sete do A Luta Social acabou por não sair, assim como também não se publicou o retrato de Ferrer que Miranda tanto desejou realizar. Tércio continuou a atuar nos jornais da cidade ${ }^{63}$ e na mobilização operária até pelo menos outubro de 1915, quando então não se tem mais notícia dele na cidade. Os documentos relacionados à sua dispensa do Exército, ${ }^{64}$ solicitada por ele já no ano seguinte na cidade do Porto, revelam seu retorno a Portugal, de onde parece

celebrações do $1^{\circ}$ de Maio que, segundo os editores, havia sucumbido à ideia de "festa do trabalho" e perdido seu caráter combativo, razão pela qual insistiam em argumentar que "a ideia de festa pretende em desvirtuar a verdadeira manifestação do operariado". Portanto, "o $1^{\circ}$ de Maio é um dia de protesto universal contra a tirania burguesa". A Lucta Social, $n^{\circ} 2$. Manaus, $1^{\circ}$ maio 1914.

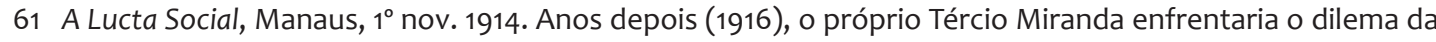
convocação para a guerra, ocasião em que, já de volta a Portugal, solicita e obtém das autoridades militares do Porto atestado de sua dispensa do Exército, datada de 1908. Arquivo Distrital do Porto (Portugal).

62 A Lucta Social, n. 6. Manaus, $1^{\circ}$ nov. 1914. De acordo com o jornal operário A União, Miranda sofreu um acidente de trabalho ao pisar, por descuido, numa correia que lançou sua perna sobre uma lançadeira, machucando-a com alguma gravidade e forçando-o a recolher-se em sua casa por alguns dias. A União, Manaus, 13 out. 1914.

63 Após sua atuação no A Lucta Social, Miranda continuou atuando na imprensa amazonense, emprestando seus serviços para a revista ilustrada Cá e Lá editada em Manaus e que tinha ateliê fotográfico próprio, onde o gráfico português recebia também encomenda de pessoas e de outros periódicos locais. Dizia um de seus anúncios: "Trabalhos tipográficos, executam-se com a máxima presteza, e por preços módicos, nas oficinas da revista Cá e Lá, como também fotogravuras, nítidas na impressão, para jornais, revistas e ilustrações. Pelo exímio fotogravador Tércio Miranda. Rua Joaquim Sarmento, 12, em frente ao Moinho Fluminense". A União, n. 14. Manaus, 27 out. 1914.

64 Requerimento $s / n^{\circ}$, Porto, Portugal, 10 jun. 1916. Arquivo Distrital do Porto, Portugal. 
não ter mais saído. Em recente pesquisa, Cláudia Amélia Mota Moreira encontrou registros que o localizam, em meados dos anos 1930, em Portugal, desolado e lançado a uma condição de penúria. ${ }^{65}$

Anos depois, oportunizando uma conjuntura de abertura política temporária favorecida pela eclosão da Revolta Tenentista de 1924, em Manaus, Tércio Miranda seria novamente lembrado e sua iniciativa de edição de um jornal destinado à organização e conscientização dos trabalhadores amazonenses posta novamente em prática com a tiragem tardia de uma "nova fase" do A Lucta Social, dessa vez assumida por Nicolau Pimentel. ${ }^{66}$

\section{À guisa de conclusão}

Tanto a imprensa operária amazonense quanto as demais fontes documentais compulsadas indicam com segurança que as trajetórias de Mariani, Azpilicueta e Miranda foram não apenas marcantes no interior do movimento operário amazonense como também agregadoras de enorme valor e significado, seja pelas ideias que defenderam, seja pela liderança que desempenharam à frente de suas categorias profissionais.

Tais lideranças atuaram num contexto adverso, em que a condição operária foi sempre marcada pela ausência de direitos protetivos e crivada por carências que se viram ainda mais agravadas após 1910, com a emergência da crise do extrativismo da borracha. Provocando falências e fechamentos de postos de trabalho, a crise lançou os trabalhadores amazonenses numa situação degradante, de pauperismo e inanição, que predispunha os trabalhadores a buscarem respostas em ações divisionistas e fragmentadoras, onde muitas vezes o operário de nacionalidade estrangeira serviu como bode expiatório.

Reagindo a esse quadro, a ação dos militantes estrangeiros aqui analisados mostrou-se fundamental, notadamente por rechaçar os princípios étnicos como norteadores do processo de organização, mobilização e luta operária. Se conviveram e, em certos casos (como o de Targino Mariani), até toleraram a presença de sociedades repatriadoras identificadas à condição nacional dos trabalhadores, nenhum deles aceitou tais critérios como válidos para a formação de instituições da classe operária em Manaus. À exceção, Mariani, Miranda e Azpilicueta assinando diversos artigos pelos jornais da grande imprensa e, em especial, da imprensa operária, foram também fundamentais para uma melhor qualificação do debate teórico acerca das ideias, conceitos e estratégias políticas e sindicais que embasavam as principais perspectivas revolucionárias do movimento operário internacional.

Além do mais, nem Tércio Miranda, nem Joaquim Azpilicueta podem ser enquadrados na categoria de meros divulgadores de ideias e doutrinas, pensadas e produzidas fora e além do contexto em que viviam e militavam. Ao contrário, seus textos e artigos partiam sempre do enfrentamento de situações concretas enfrentadas pelos trabalhadores em Manaus e, a partir de tais situações e problemas, propunham ações e reflexões que iluminavam igualmente a problemática, os temas e as questões que estavam sendo, à época, colocadas pelo

65 BARROS, Cláudia Amélia Mota Moreira. "Vozes Operárias: os tipógrafos na construção da identidade operária amazonense (1900-1920)". (Dissertação de mestrado em História. Universidade Federal do Amazonas, 2016), p. 87.

66 A Lucta Social, Manaus, 10 ago. 1924. 
debate voltado para a emancipação da classe operária. São, portanto, lideranças que com sua atuação intelectual, tanto quanto sua prática política, colaboraram no debate mais amplo e coletivo que foi, pouco a pouco, consubstanciando os ideais socialistas no mundo todo.

Se, ao fim e ao cabo, suas militâncias não conseguiram afastar de todo o movimento operário amazonense do "tronco da beneficência", certamente o fragilizaram, tendo seus ensinamentos doutrinários colaborado sensivelmente para dar vazão a um conjunto de novas organizações operárias entre o final da década de 1910 e o início da década de 1920.

Dialogando com os trabalhadores amazonenses de seu tempo, divergiram e convergiram quanto aos caminhos a serem trilhados; ensinaram e aprenderam numa construção coletiva que, na luta e na camaradagem estabelecida no interior das oficinas, dos armazéns do porto, das ruas ou das praças forjaram suas identidades de lideranças operárias efetivamente empenhadas na construção de um mundo novo, mais justo e solidário.

Enviado: 20/06/2016

Aprovado: 20/03/2017 